\title{
Thin-Layer Hydroxyapatite Deposition on a Nanofiber Surface Stimulates Mesenchymal Stem Cell Proliferation and Their Differentiation into Osteoblasts
}

\author{
Eva Prosecká, ${ }^{1,2}$ Matej Buzgo, ${ }^{1,2}$ Michala Rampichová,, 2 Tomáš Kocourek, ${ }^{3}$ Petra Kochová, ${ }^{4}$ \\ Lucie Vysloužilová, ${ }^{5}$ Daniel Tvrdík, ${ }^{6}$ Miroslav Jelínek, ${ }^{3}$ David Lukáš, ${ }^{5}$ and Evžen Amler ${ }^{1,2,7}$ \\ ${ }^{1}$ Laboratory of Tissue Engineering, Institute of Experimental Medicine, Academy of Science of the Czech Republic, Videnska 1083, \\ 14240 Prague, Czech Republic \\ ${ }^{2}$ Department of Biophysics, 2nd Faculty of Medicine, Charles University in Prague, V Uvalu 84, 15006 Prague 5, Czech Republic \\ ${ }^{3}$ Department of Natural Sciences, Czech Technical University in Prague, Zikova 1905/4, 16636 Prague 6, Czech Republic \\ ${ }^{4}$ Department of Mechanics, Faculty of Applied Sciences, University of West Bohemia, Univerzitni 8, 30614 Pilsen, Czech Republic \\ ${ }^{5}$ Department of Nonwoven Textiles, Faculty of Textile Engineering, Technical University of Liberec, Liberec 461 17, Czech Republic \\ ${ }^{6}$ Institute of Pathology, First Faculty of Medicine, General Teaching Hospital, Charles University, Studnickova 2, \\ 12800 Prague, Czech Republic \\ ${ }^{7}$ Department of Medicine and Humanities, Faculty of Biomedical Engineering, Czech Technical University in Prague, Sítná 3105 , \\ 27201 Kladno, Czech Republic
}

Correspondence should be addressed to Evžen Amler, evzen.amler@lfmotol.cuni.cz

Received 15 June 2011; Accepted 19 October 2011

Academic Editor: Ji Wu

Copyright ( 2012 Eva Prosecká et al. This is an open access article distributed under the Creative Commons Attribution License, which permits unrestricted use, distribution, and reproduction in any medium, provided the original work is properly cited.

\begin{abstract}
Pulsed laser deposition was proved as a suitable method for hydroxyapatite (HA) coating of coaxial poly- $\varepsilon$-caprolactone/polyvinylalcohol (PCL/PVA) nanofibers. The fibrous morphology of PCL/PVA nanofibers was preserved, if the nanofiber scaffold was coated with thin layers of HA $(200 \mathrm{~nm}$ and $400 \mathrm{~nm})$. Increasing thickness of HA, however, resulted in a gradual loss of fibrous character. In addition, biomechanical properties were improved after HA deposition on PCL/PVA nanofibers as the value of Young's moduli of elasticity significantly increased. Clearly, thin-layer hydroxyapatite deposition on a nanofiber surface stimulated mesenchymal stem cell viability and their differentiation into osteoblasts. The optimal depth of HA was $800 \mathrm{~nm}$.
\end{abstract}

\section{Introduction}

Stem cells have undoubtedly been at the center of interest and the object of intensive study in the last decade [1-3]. Clearly, multiple stem cells have, under suitable conditions, the potential to differentiate cell lineages and thus play a key role in tissue engineering and regenerative medicine. Several sources of stem cells have been described, including muscle $[4,5]$, synovium [6], periosteum [7], and bone marrow [8, 9]. Stem cells can be also isolated from adipose tissue, which can be obtained under local anesthesia with minimal discomfort $[10,11]$. However, bone marrow is most widely utilized as a source of autologous MSCs. These cells can differentiate into osteogenic lineages when cultured in the presence of dexamethasone, ascorbic acid, and $\beta$-glycerophosphate [12] and potentially used for treating large bone defects. Autologous stem cells as the source of donor cells have numerous advantages for regenerative medicine. These include low donor site morbidity, a diminished or absent immune response, and a high proliferative potential $[1,2]$.

In fact, other growth factors such as transforming growth factor (TGF- $\beta$ ), insulin-like growth factor (IGF), and basic fibroblast growth factor (bFGF) have been described as stimulators of MSCs proliferation and osteogenic differentiation $[13,14]$. The process of stem cell differentiation is undoubtedly complicated and time and concentration dependent. Thus, the main challenge of the successful application of MSCs in regenerative medicine seems to be the regulated release of a suitable concentration of differentiation factors, particularly under in vivo conditions. This is among the goals 
of tissue engineering as a multidisciplinary field focusing on the reconstruction of biological tissues. Cells, especially autologous cells, and smart (functionalized) scaffolds enriched with growth factors, preferentially serving as a controlled delivery device, are fundamental components in the engineering of novel cell proliferation and differentiation systems [2].

Surface modification is one of the essential steps in constructing artificial cell-seeded systems. HA, which is similar to the apatite of living bone, can be used as a suitable material for improving cell proliferation and differentiation into osteoblasts. HA has been used in medicine and dentistry for over 20 years due to its biocompatibility and osteoconductivity and its excellent chemical and biological affinity with bone tissue $[15,16]$. HA coatings of bone implants enable fast bony adaptation and reduced healing time [1719]. There are a number of techniques used to produce thin HA films. Plasma-sprayed HA coatings, where HA is bound mechanically, have limited chemical bonding, and cracks, pores, and other impurities limit their mechanical strength in contact with a substrate and the stability of the layer $[20,21]$. Another coating technique is ion beam sputtering, producing an amorphous coating. Subsequently, heat treatment is necessary to produce crystals $[22,23]$. Very high temperatures, necessary for crystallization, are not favorable for nonmetallic materials such as polymers or bioactive molecules. Pulsed laser deposition (PLD) is mostly used as an alternative technique of HA coating [24, 25]. PLD employs an intense laser beam for material evaporation. Subsequent condensation on a mat can create a very thin layer (depth of several atoms only). The material surface properties are, consequently, directly dependent on the deposition conditions.

Aside from chemical and surface charge modification, the surface's physical properties are also vital for successful cell seeding on scaffolds. Nanotechnology is the term used to cover the design, construction, and utilization of functional structures with at least one characteristic dimension measured in nanometers and brings a new chance to stem cells research and development [26-28].

Electrospun nanofibers are novel materials characterized by an enormous surface to volume ratio, high porosity, and a structure resembling that of the extracellular matrix, thus facilitating their use in a broad range of applications $[29,30]$. These properties predestined the use of nanofibers in various tissue engineering applications. In addition, nanofibers can also serve as drug delivery systems. Nanofibers have been utilized for the delivery of both water soluble and water insoluble substances $[31,32]$. Due to their enormous surface area, nanofibers enable the adhesion of diverse bioactive agents, such as growth factors [33], enzymes [34], or nucleic acids [35]. The release kinetics of the content is determined by the form of the interaction between the fibers and the adhered drug. If the drug is noncovalently attached to the nanofiber surface, the interaction is weak, and a quick burst release occurs. For nonbiodegradable materials, the diffusion rate of the drug from the fibers depends strongly on the physiochemical properties of the delivered substances, such as the molecular weight, hydrophobicity, and charge of the molecule. For biodegradable materials, the process additionally depends also on the kinetics of the material's degradation, which for rapidly degradable materials is significantly hastened [29]. Clearly, drugs dissolved or dispersed in materials from which nanofibers are produced can be quickly released. However, healing processes often require a slower release on a scale of days or even weeks. This is especially important in vivo.

To overcome this obstacle, the incorporation of bioactive substances in the interior of the nanofiber has been employed. This can be achieved either by blend electrospinning or by coaxial electrospinning. Blend electrospinning is a single-step method enabling the incorporation of various bioactive substance [32]. The disadvantage of the process is its limitation by the compatibility of the delivered substances with the polymer solvent. Thus, blend electrospinning is not suitable for the delivery of proteins with polymers soluble only in organic solvents. Despite these constraints, blend electrospinning is a fast and convenient method for the microencapsulation of antibiotics [36, 37], anticancer drugs [38-42], proteins [43-45], DNA [46, 47], and siRNA [48]. Recently, coaxial electrospinning was introduced as a novel method for drug delivery resulting in the production of coreshell nanofibers [49]. The nanofiber core and shell could be prepared either from the same polymer solution or from different polymer solutions, thus combining the advantages of both polymer systems. Such systems could deliver highly susceptive substances in combination with various polymer systems without altering their structure or function. Electrospun coaxial fibers have been employed for the delivery of various bioactive substances, for example, proteins [50-52], DNA [46], and siRNA [48]. In addition, further drug encapsulation in the nanofiber core, such as in liposomes, can significantly prolong drug release from the nanofiber interior.

The aim of the present study was to introduce a modern system suitable for the treatment of bone defects. This system is based on MSCs and functionalized nanofibers. The nanofibers can be modified on their surface as well as enriched in their core with different drugs that could be slowly released over the course of days or weeks.

\section{Methods}

2.1. Materials and Reagents. Poly-E-caprolactone (PCL, MW 45000), FITC-dextran, MTT, glycerol 2-phosphate disodium salt hydrate, BCECF-AM, and PCR primers were purchased from Sigma-Aldrich (Germany). Polyvinylalcohol sloviol (PVA) was purchased from Novacke Chemicke Zavody (Slovak republic). Hydroxyapatite was obtained in the form of a pressed powder (Lasak, Czech Republic). Gelofusine was purchased from B. Braun Melsungen (Germany). $\alpha$-MEM cultivation medium and foetal bovine serum were purchased from PAA (Austria). Double-strand-specific dye for PCR analysis, SYBR Green I, was purchased from Roche (Roche Diagnostics, Mannheim, Germany) and an RNeasy Mini Kit for RNA isolation from Qiagen (Germany).

2.2. Coaxial Electrospinning of PCL/PVA Nanofibers. A $14 \%$ $(\mathrm{w} / \mathrm{v})$ PCL solution was prepared as the shell solution by dissolving $7 \mathrm{~g}$ PCL in $50 \mathrm{~mL}$ chloroform/ethanol $(8: 2)$ and 
stirring at room temperature. The core solution consisted of 5\% PVA (v/v). The coaxial spinneret apparatus consisted of two needles placed together coaxially [53]. Two syringe pumps were used to deliver the core and shell solutions, respectively. A high-voltage power supply was used to generate voltages of up to $60 \mathrm{kV}$, and a span bond was used as the receiving plate to collect the electrospun nanofibers. The distance between the tip of the syringe needle and the collecting plate was $12 \mathrm{~cm}$. All electrospinning processes were performed at room temperature with $56 \%$ humidity. In case of the release study, the core solution consisted of FITC-dextran $(2 \mathrm{mg} / \mathrm{mL}, 10,000 \mathrm{MW}$ ) dissolved either in $1 \%, 3 \%$, or $5 \%$ $(\mathrm{v} / \mathrm{v})$ PVA. The process was performed on the apparatus described above at room temperature with $52 \%$ humidity.

2.3. HA Coatings of Nanofibers. Prepared nanofibers were coated by $\mathrm{HA}$ layers of different thickness. HA $\left[\mathrm{Ca}_{10}\left(\mathrm{PO}_{4}\right)_{6}(\mathrm{OH})_{2}\right]$ films were created by a $\mathrm{KrF}$ excimer laser (COMPexPro $205 \mathrm{~F}$ ) of $248 \mathrm{~nm}$ wavelength, frequency $10 \mathrm{~Hz}$, and energy $600 \mathrm{~mJ}$. The energy density of the laser beam was $2 \mathrm{Jcm}^{-2}$. The deposition proceeded in an $\mathrm{H}_{2} \mathrm{O}+$ $\mathrm{Ar}$ atmosphere at a pressure of $40 \mathrm{~Pa}$. The substrate was fixed at a distance of $5 \mathrm{~cm}$ from the target HA material (cake of pressed powder). The substrate was at room temperature. HA films of 200 (PCL/PVA200HA), 400 (PCL/PVA400HA), and $800 \mathrm{~nm}$ thickness (PCL/PVA800HA) were grown. Pure PCL/PVA core-shell nanofibers were used as a control (PCL/ PVA).

2.4. Characterization of the Scaffolds. The prepared nanofibrous scaffolds were characterized by scanning electron microscopy. Air-dried samples of electrospun HA-coated nanofibers were mounted on aluminum stubs and sputter-coated with a layer of gold approximately $60 \mathrm{~nm}$ thick using a Polaron sputter-coater (SC510, Polaron, Now Quorum Technologies Ltd.). The samples were examined in an Aquasem (Tescan) scanning electron microscope in the secondary electron mode at $15 \mathrm{kV}$.

2.5. Biomechanical Characterization of Scaffolds. Young's moduli of elasticity, ultimate stresses, and ultimate strains of the scaffolds were obtained at room temperature using a Zwick/Roell traction machine equipped with a $1 \mathrm{kN}$ load cell. Because of the difficulty to produce the layer of PCL/PVA nanofibers of uniform thickness, only the samples with the same thickness of the basic layer of PCL/PVA nanofibers of pure samples as well as with the layer of HA were used for mechanical testing. Thus, the samples without layer of HA were signed as type I $(n=4)$ and with the HA layer as type II $(n=7)$. The samples themselves were thin strips of the nanofibers. The initial length of all samples was $10 \mathrm{~mm}$. The width of all samples was $10 \mathrm{~mm}$. The thickness of individual samples was about $60 \mu \mathrm{m}$. The samples were prepared according to studies $[54,55]$. The template of the paper $20 \times 50 \mathrm{~mm}$ (height $\times$ width) with the centered rectangular hole $10 \times 40 \mathrm{~mm}$ was cut, and lines marking $10 \mathrm{~mm}$ wide sample strips were drawn on its top and bottom stripes. Then it was glued to the sheet of the composite, and two other strips of paper $5 \times 50 \mathrm{~mm}$ were glued to the back faces of the top and bottom stripes. Then the individual scaffolds were cut resulting in four $20 \times 10 \mathrm{~mm}$ stripes consisting of $10 \times$ $10 \mathrm{~mm}$ sample between two $5 \times 10 \mathrm{~mm}$ grips of paper.

The tensile test with a loading velocity of $10 \mathrm{~mm} / \mathrm{min}$ was applied to the samples. The load was applied until the scaffold ruptured. Young's moduli of elasticity were determined using linear regression of the stress-strain curves at a strain of approximately 1-6\% (linear region depending on the shape of the curve). The ultimate stress and the ultimate strain were determined at the start of the rupture. The stress was defined as the force divided by the initial area, and the strain was defined as the elongation of the specimen divided by its initial length. Our own software written in Python programming language was used for evaluation [56].

2.6. Isolation and Cultivation of MSCs. Blood marrow aspirates were obtained from the os ilium (tuber coxae Ala ossis iili) of anesthetized miniature pigs (age 6-12 months). The bone marrow blood was aspirated into a $10 \mathrm{~mL}$ syringe with $5 \mathrm{~mL}$ Dulbecco's phosphate buffered saline (PBS), 2\% fetal bovine serum (FBS), and $25 \mathrm{IU}$ heparin/ $\mathrm{mL}$ connected with a bioptic needle ( $15 \mathrm{G} / 70 \mathrm{~mm})$. Under sterile conditions, the bone marrow blood (about $20 \mathrm{~mL}$ ) was placed into $50 \mathrm{~mL}$ centrifuge tubes and $5 \mathrm{~mL}$ of gelofusine was added. After 30 min incubation at room temperature, the blood was centrifuged at $400 \times \mathrm{g}$ for $15 \mathrm{~min}$. Subsequently, the layer of mononuclear cells was removed and seeded into a culture flask, then cultured at $37^{\circ} \mathrm{C}$ in a humidified atmosphere with $5 \%$ $\mathrm{CO}_{2} . \alpha$-MEM medium with Earle's Salt and L-glutamine supplemented with 10\% FBS and penicillin/streptomycin ( $100 \mathrm{IU} / \mathrm{mL}$ and $100 \mu \mathrm{g} / \mathrm{mL}$, resp.) was used as the culture medium.

2.7. MSCs Seeding on the Scaffolds. Scaffolds were cut into a round shape with a diameter of $6 \mathrm{~mm}$ and sterilized using ethylenoxid. Cells were seeded on the scaffolds at a density of $70 \times 10^{3} / \mathrm{cm}^{2}$ in a 96-well plate. Scaffolds with seeded MSCs were cultivated in differentiation media: $\alpha$-MEM supplemented with $10 \% \mathrm{FBS}$, penicillin/streptomycin (100 IU/ $\mathrm{mL}$ and $100 \mu \mathrm{g} / \mathrm{mL}$, resp.), $100 \mathrm{nM}$ dexamethasone, $40 \mu \mathrm{g} /$ $\mathrm{mL}$ ascorbic acid-2-phosphate and $10 \mathrm{nM}$ glycerol 2-phosphate disodium salt hydrate. The medium was changed every 3 days.

2.8. Cell Proliferation Analysis by the MTT Test. $50 \mu \mathrm{L}$ of [3-(4,5-dimethylthiazol-2-yl)-2,5-diphenyltetrazolium bromide] (MTT), and $1 \mathrm{mg} / \mathrm{mL}$ in PBS (pH 7.4) were added to $150 \mu \mathrm{L}$ of sample medium and incubated for 4 hours at $37^{\circ} \mathrm{C}$. The MTT was reduced by the mitochondrial dehydrogenase of normally metabolizing cells to purple formazan. Formazan crystals were solubilized with $100 \mu \mathrm{L}$ of $50 \%$ N,Ndimethylformamide in $20 \%$ sodium dodecyl sulfate (SDS) at $\mathrm{pH}$ 4.7. The results were examined by spectrophotometry in an ELISA reader at $570 \mathrm{~nm}$ (reference wavelength $690 \mathrm{~nm}$ ).

2.9. Cell Proliferation Analysis by PicoGreen. The PicoGreen assay was carried out using the Invitrogen PicoGreen assay kit (Invitrogen Ltd., Paisley, UK). The proliferation of MSCs on scaffolds was tested on days 1,7 , and 14. To process 
material for the analysis of DNA content, $250 \mu \mathrm{L}$ of cell lysis solution $(0.2 \% \mathrm{v} / \mathrm{v}$ Triton $\mathrm{X}-100,10 \mathrm{mM}$ Tris $(\mathrm{pH} 7.0)$, $1 \mathrm{mM}$ EDTA) was added to each well containing a scaffold sample. To prepare the cell lysate, the samples were processed through a total of three freeze/thaw cycles, scaffold sample was first frozen at $-70^{\circ} \mathrm{C}$ and thawed at room temperature. Between each freeze/thaw cycle scaffolds were roughly vortexed. Prepared samples were stored at $-70^{\circ} \mathrm{C}$ until analysis. To quantify cell number on scaffolds, a cellbased standard curve was prepared using samples with known cell numbers (range 100-106 cells). The DNA content was determined by mixing of $100 \mu \mathrm{L}$ PicoGreen reagent and $100 \mu \mathrm{L}$ of DNA sample. Samples were loaded in triplicate and florescence intensity was measured on a multiplate fluorescence reader (Synergy HT, $\lambda_{\mathrm{ex}}=480-500 \mathrm{~nm}, \lambda_{\mathrm{em}}=520$ $540 \mathrm{~nm})$. Measured data were used for derivation of absorbance values measured by MTT assay to cell counts on the scaffolds.

2.10. Viability of Cells Seeded on Scaffolds. For determining cell viability, live/dead staining (BCECF-AM/propidium iodide) and visualization using confocal microscopy was performed. 2', 7'-bis(2carboxyethyl)-5(6)-carboxyfluorescein acetoxymethyl ester (BCECF-AM, diluted $1: 100$ in medium) was added to cell-seeded scaffolds and incubated for $45 \mathrm{~min}$ at $37^{\circ} \mathrm{C}$ and $5 \% \mathrm{CO}_{2}$ for live cell detection, then rinsed with PBS ( $\mathrm{pH} 7.4)$; propidium iodide $(5 \mu \mathrm{g} / \mathrm{mL}$ in $\mathrm{PBS} \mathrm{pH} 7.4$ ) was added for $10 \mathrm{~min}$, rinsed with $\mathrm{PBS}(\mathrm{pH} 7.4)$ again, and visualized using a Zeiss LSM 5 DUO confocal microscope (wavelengths: BCECF-AM $\lambda_{\mathrm{exc}}=488 \mathrm{~nm}$ and $\lambda_{\mathrm{em}}=505-$ $535 \mathrm{~nm}$; propidium iodide $\lambda_{\mathrm{exc}}=543 \mathrm{~nm}$ and $\lambda_{\mathrm{em}}=630-$ $700 \mathrm{~nm})$.

2.11. Quantitative Real-Time PCR Analysis. Total RNA was extracted using an RNeasy Mini Kit according to the manufacturer's protocol. Total RNA was stored at $-20^{\circ} \mathrm{C}$.

The cDNA from $1 \mu \mathrm{g}$ of total RNA was used as a template. The synthesis of cDNA was performed by a standard procedure described in our previous work [57]. Bone sialoprotein (BS) and osteocalcin (OC) mRNA expression levels were quantified by means of a LightCycler 480 (Roche Diagnostics, Mannheim, Germany) using the double-strandspecific dye SYBR Green I according to the manufacturer's protocol. Primers used were as follows: BS, sense $5^{\prime}$-CGA CCA AGA GAG TGT CAC-3' ${ }^{\prime}$, antisense $5^{\prime}$-GCC CAT TTC TTG TAG AAG C-3' (498 bp); OC, sense 5' -TCA ACC CCG ACT GCG ACG AG-3', antisense 5' ${ }^{\prime}$ TTG GAG CAG CTG GGA TGA TGG-3' (204 bp) and beta-actin, sense 5' -AGG CCA ACC GCG AGA AGA TGA CC-3', antisense 5'-GAA GTC CAG GGC GAC GTA GCA C-3' (332 bp). The PCR conditions were initial denaturation at $95^{\circ} \mathrm{C}$ for $10 \mathrm{~min}$, followed by 45 cycles of denaturation at $95^{\circ} \mathrm{C}$ for $15 \mathrm{~s}$, annealing at $57^{\circ} \mathrm{C}$ for $10 \mathrm{~s}$, and extension at $72^{\circ} \mathrm{C}$ for $20 \mathrm{~s}$. The expression levels of BS and OC mRNAs were normalized using the level of beta-actin mRNA as a housekeeping gene and expressed as the ratio to actin. Student's $t$-test was used to evaluate the statistical significance of the results. Differences with $P$ values $<0.05$ were considered significant.
2.12. Measurement of FITC-Dextran Release Profile. In order to study the release profile of FITC-dextran, core-shell nanofiber meshes with either 1\% PVA, 3\% PVA, or 5\% PVA were cut into round patches and incubated with $1 \mathrm{~mL}$ of TBS buffer at room temperature. At specific intervals, the TBS buffer was withdrawn and replaced with fresh buffer. The time interval was determined keeping in mind the balance between the release of a detectable amount of FITC-dextran and maintenance of the sink condition. Drug release was quantified using fluorescence spectroscopy. Briefly, $200 \mu \mathrm{L}$ of samples and blank samples were measured on a multiplate fluorescence reader (Synergy HT, $\lambda_{\mathrm{ex}}=480-500 \mathrm{~nm}, \lambda_{\mathrm{em}}=$ $520-540 \mathrm{~nm}$ ) and background subtraction was performed. The cumulative release profile of FITC-dextran was obtained, and the half time of release was determined as the time at which the initial fluorescence intensity $\mathrm{I}_{0}$ decreased to $I=$ $I_{0} \cdot e^{-1}$.

2.13. Statistical Analysis. Quantitative data are presented as mean \pm standard deviation (SD). For in vitro tests, average values were determined from at least three independently prepared samples. Results were evaluated statistically using one-way analysis of variance (ANOVA) and the StudentNewman-Keuls Method. The Shapiro-Wilk's $W$ test was used to determine the normality of the Young's moduli of elasticity, ultimate strains, and ultimate stresses. The $t$-test was used to determine the differences between values of mechanical parameters obtained for pure PCL/PVA scaffolds (type I) and scaffolds covered by HA (type II).

\section{Results and Discussion}

3.1. Scaffold Characterization. Coaxial core-shell nanofibers were prepared from PCL as a shell material and PVA as a core material. PCL has good biocompatibility and enables the successful cultivation of MSCs [58] and osteogenic cells [59]. On the other hand, PVA is a water-soluble material and has been employed as a suitable substance for the delivery of bioactive compounds from the nanofiber core [60]. To improve the surface parameters for MSCs seeding, coaxial nanofibers were further functionalized by pulsed laser deposition of HA. Thin layers of 200, 400, or $800 \mathrm{~nm}$ thickness were deposited onto the nanofiber surface. HA deposition clearly modified the nanofiber surface and significantly influenced the surface properties. Scanning electron microscopy revealed the fibrous morphology of PCL nanofibers (Figure 1(a)). This is in accordance with our previous results [61]. Pulsed laser deposition of a $200 \mathrm{~nm}$ thick HA layer did not affect the fibrous morphology or porosity of the nanofibers (Figure $1(\mathrm{~b}))$. However, the fibrous character of samples with a $400 \mathrm{~nm}$ thick HA layer (Figure 1(c)) was less well preserved, and the porosity of the scaffold decreased. The fibrous morphology disappeared completely in samples with a $800 \mathrm{~nm}$ thick HA coating (Figure $1(\mathrm{~d})$ ).

3.2. Biomechanical Testing. The effect of an HA layer on the biomechanical properties of the nanofibers was tested using a tensile test. Young's moduli of elasticity, the ultimate stresses, and the ultimate strains of scaffolds of PCL/PVA 


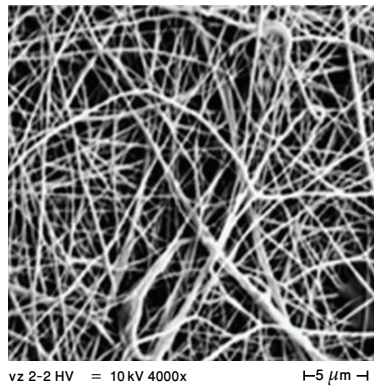

(a)

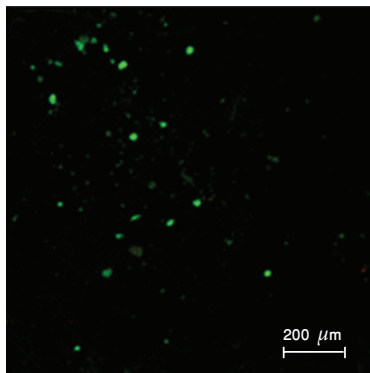

(e)

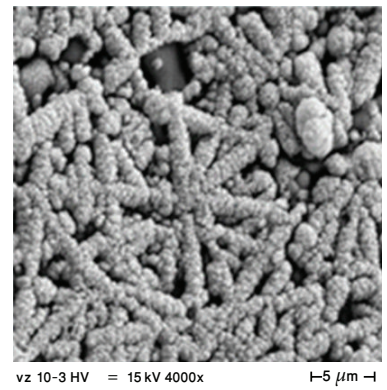

(b)

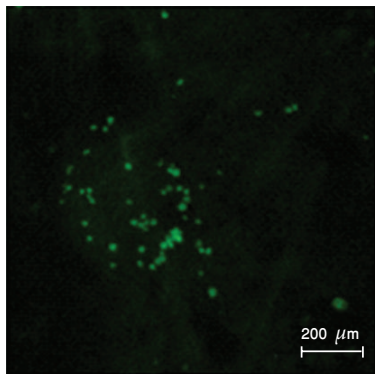

(f)

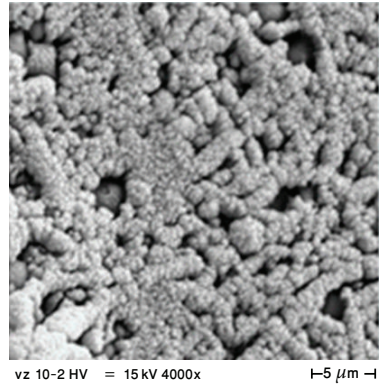

(c)

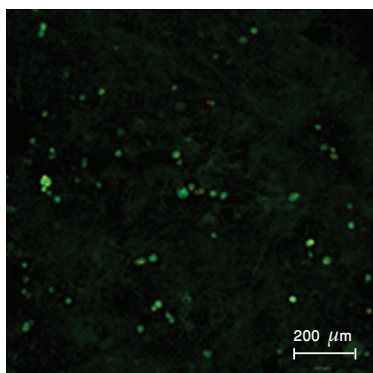

(g)

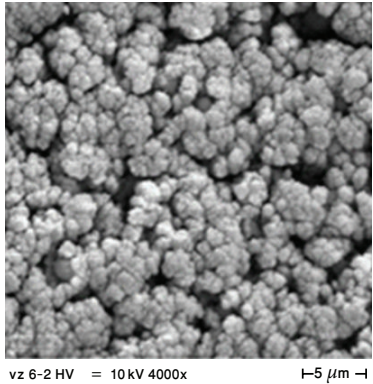

(d)

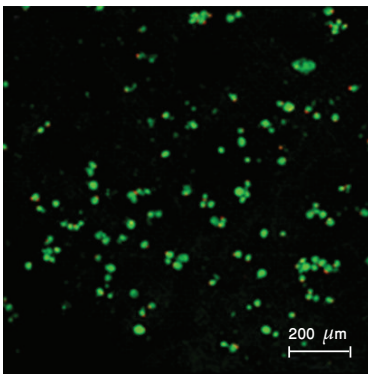

(h)

FIGURE 1: Visualization of scaffolds by SEM and confocal microscopy. Prepared scaffolds were visualized using SEM (a, b, c, d). On day 7 , MSCs were stained using BCECF-AM and propidium iodide for live/dead staining, and samples were visualized by confocal microscopy (e, f, g, h); PCL/PVA (a, e), PCL/PVA200HA (b, f), PCL/PVA400HA (c, g), and PCL/PVA800HA (d, h).

nanofibers and various amounts of HA were determined at room temperature using a Zwick/Roell traction machine. We found significant differences in Young's moduli of elasticity between samples without an HA layer and those with an HA layer $(P=0.04)$. Young's moduli of elasticity in the case of pure PCL/PVA nanofibers was $1.76 \pm 0.50 \mathrm{Mpa}$ while that for the samples with an HA layer was $5.40 \pm 3.09 \mathrm{MPa}$; the difference was significant (see Figure 4(a)). Significant differences between these two groups were found as well in the case of ultimate strains $(P<0.001)$. Here, the value obtained for pure PCL/PVA scaffolds was $0.23 \pm 0.03$, while for scaffolds with an HA layer the value was $0.09 \pm 0.04$, (see Figure 4(b)). No significant differences were found when analyzing ultimate stresses $(P=0.26)$, although the value for the group with an $\mathrm{HA}$ layer, $0.36 \pm 0.27 \mathrm{MPa}$, was higher than that for the pure PCL/PVA scaffolds, $0.19 \pm 0.07 \mathrm{MPa}$ (see Figure $4(\mathrm{c})$ ). The results showed that from the mechanical point of view, a PCL/PVA scaffolds covered by an HA layer is the relevant choice as a scaffold material for other studies and applications in which greater stiffness is required.

\subsection{Proliferation and Viability of MSCs Seeded on Scaffolds.} To test the scaffolds' biocompatibility and their ability to stimulate the proliferation and differentiation of MSCs into osteogenic cells, MSCs were seeded on scaffolds and cultivated for 14 days. Their proliferation and viability were determined on days 1, 7, and 14. Cell proliferation was determined by the PicoGreen assay and confocal microscopy (Figure 2). Viability was determined by the widely used MTT assay. Clearly, the deposition of a $400 \mathrm{~nm}$ or $800 \mathrm{~nm}$ thick HA layer resulted in the highest absorbance, which in turn reflected the best cell viability. However, some publications have reported that the MTT test is affected by cell number [62]. In order to correct for the possible inaccuracy of the MTT assay, we performed the PicoGreen assay as well. PicoGreen is a highly sensitive probe for dsDNA and thus can be used to determine cell numbers. Consequently, we performed both the MTT assay and the PicoGreen assay and correlated both results. This approach enabled the calibration of the absorbance measured in the MTT assay to the cell number determined by PicoGreen. By comparing the results of both assays in this manner, we were able to derive reliable data on cell viability (Figure 2). The results showed that in the control samples (PCL/PVA), cell viability was only slightly elevated. On the other hand, samples coated with HA showed a marked increase in cell viability. The highest viability was detected for samples with a $400 \mathrm{~nm}$ or $800 \mathrm{~nm}$ thick HA coating.

This conclusion was clearly supported by our confocal microscopy observations. MSC viability on the scaffolds was characterized by BCECF-AM and propidium iodide in the presence of an HA coating (Figures 1(e)-1(h)). The largest cell population was found in the samples with an $800 \mathrm{~nm}$ thick HA coating (Figure 1(h)), which is in agreement with the results of the PicoGreen assay.

3.4. Osteogenic Differentiation of MSCs. A positive influence of HA on osteogenesis has been demonstrated in many reports $[4,63,64]$. On the other hand, Wang et al. pointed out the significance of HA structures for proliferation and found higher cell proliferation rates on microsized HA particles than on nanosized ones [65]. Ribeiro et al. also found improved cell viability and proliferation of osteoblastic 


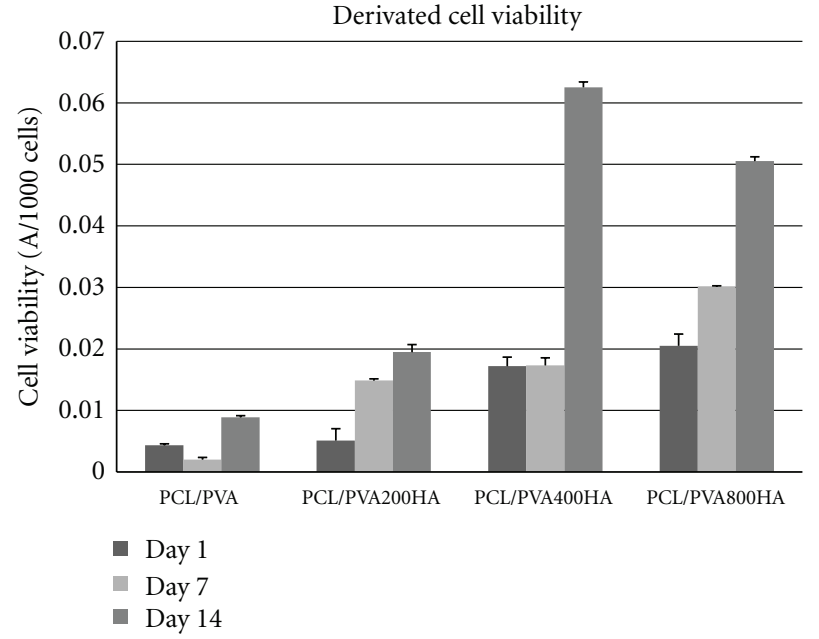

(a)

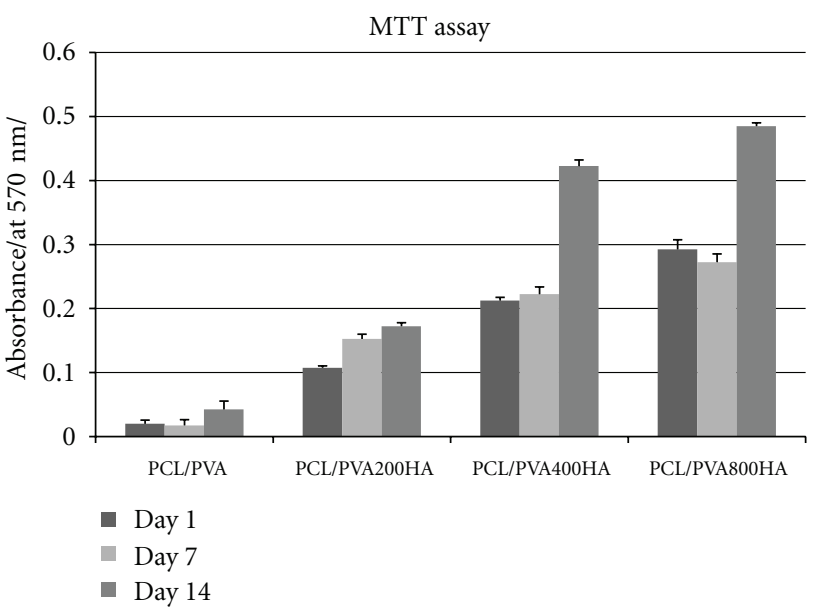

(b)

Figure 2: Cell metabolic activity and viability. Metabolic activity of viable MSCs was detected by MTT assay on day 1,7 , and 14 (mean \pm standard deviation). Results of MTT assay for PCL/PVA, PCL/PVA200HA, PCL/PVA400HA, and PCL/PVA800HA samples (a). Cell viability calculated as derivation of absorbance values from MTT assay to cell counts determined by PicoGreen assay (b).

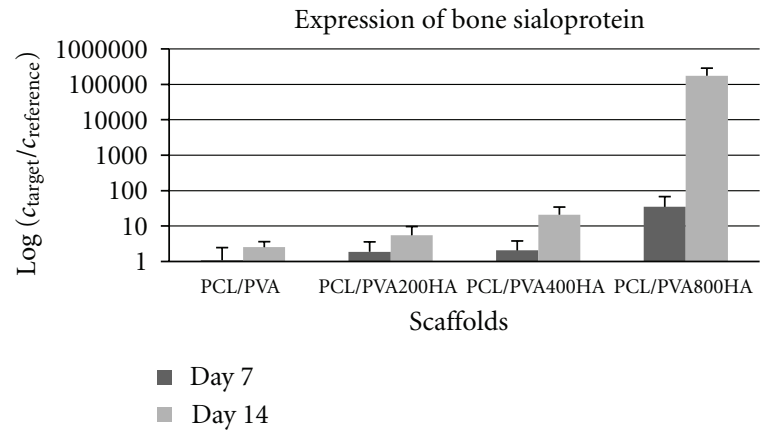

(a)

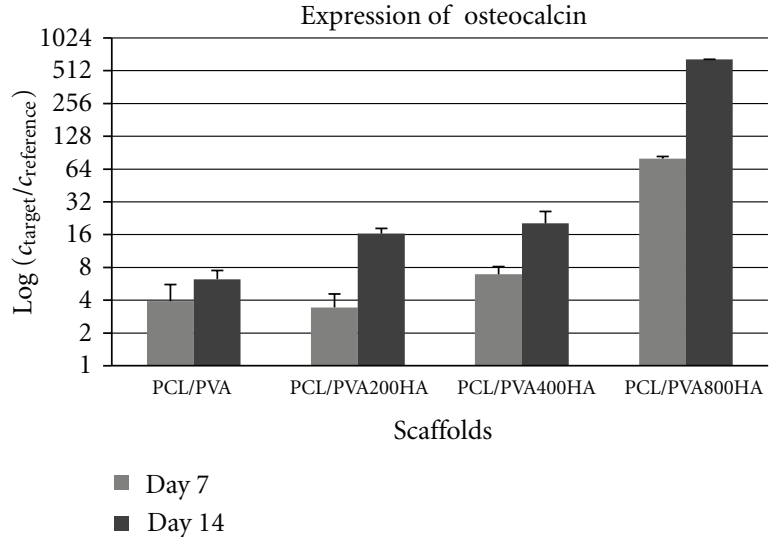

(b)

FIGURE 3: Expression of BS (a) and OC (b) genes. Osteogenic differentiation of MSCs was detected by PCR analysis of expresion BS and OC genes on day 7 and 14 (mean \pm standard deviation).

MC3T3-E1 cells on HA particles of larger size [66]. However, there is no clear evidence so far on the effect of HA on differentiation into osteogenic cells. Therefore, the effect of HA coating of nanofibers on the osteogenic differentiation of MSCs was studied using real-time PCR analysis. The expression levels of BS and OC mRNAs, osteogenic markers, were detected on day 7 and 14 for all samples (Figures 3(a) and 3 (b)). Interestingly, the samples with an $800 \mathrm{~nm}$ thick HA coating were characterized by the significantly higher expression of BS and OC genes than the pure PCL/PVA samples. Based on our results, we can hypothesize that HA-modified nanofibers induced cell differentiation and also improved cell viability (Figure 2).

3.5. Release Profile of FITC-Dextran. Besides surface modifications, possibilities exist for drug distribution into the nanofiber core. The encapsulation of different proliferation agents inside the nanofibers can increase their ability to stimulate proliferation and thus further improve the positive effect of nanofiber scaffolds on MSCs proliferation and differentiation. This could be especially important in combination with the already described positive effect of HA deposition on MSCs viability and differentiation. Knowledge of the release profile from HA-coated nanofibers seems to be a key point for the construction of novel drug-delivery systems suitable for bone tissue engineering.

To study the release profile from coaxially electrospun nanofibers with different concentrations of core polymer, FITC-dextran incorporated into the nanofiber core was employed as the monitoring fluorescence probe. The FITCdextran samples were incubated at room temperature in TBS buffer, which was subsequently replaced with fresh buffer as 


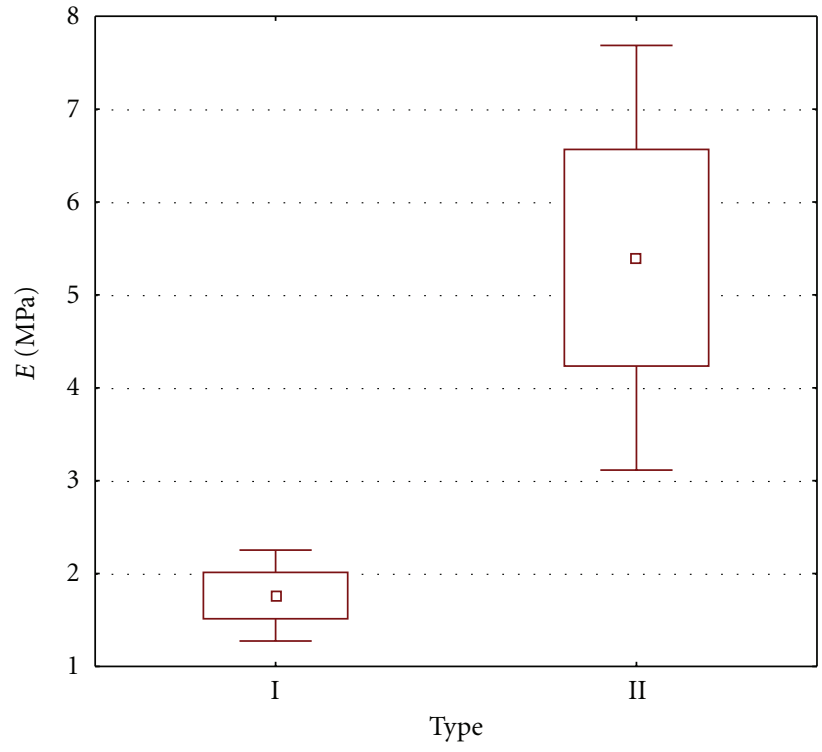

Mean

$\square$ Mean \pm SE

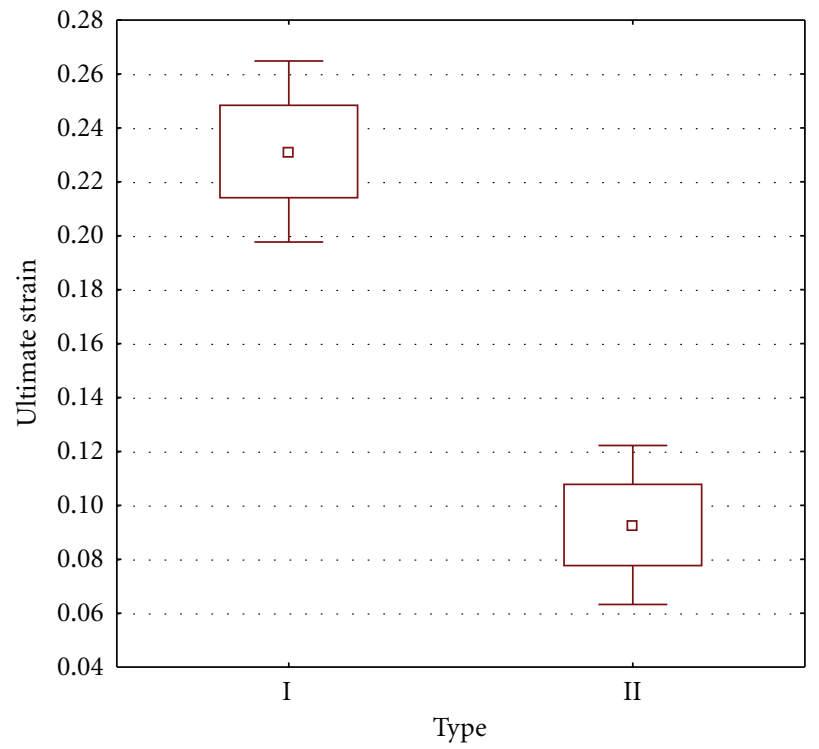

口 Mean

I Mean $\pm 1.96 * \mathrm{SE}$

$\square$ Mean \pm SE

(a)

(b)

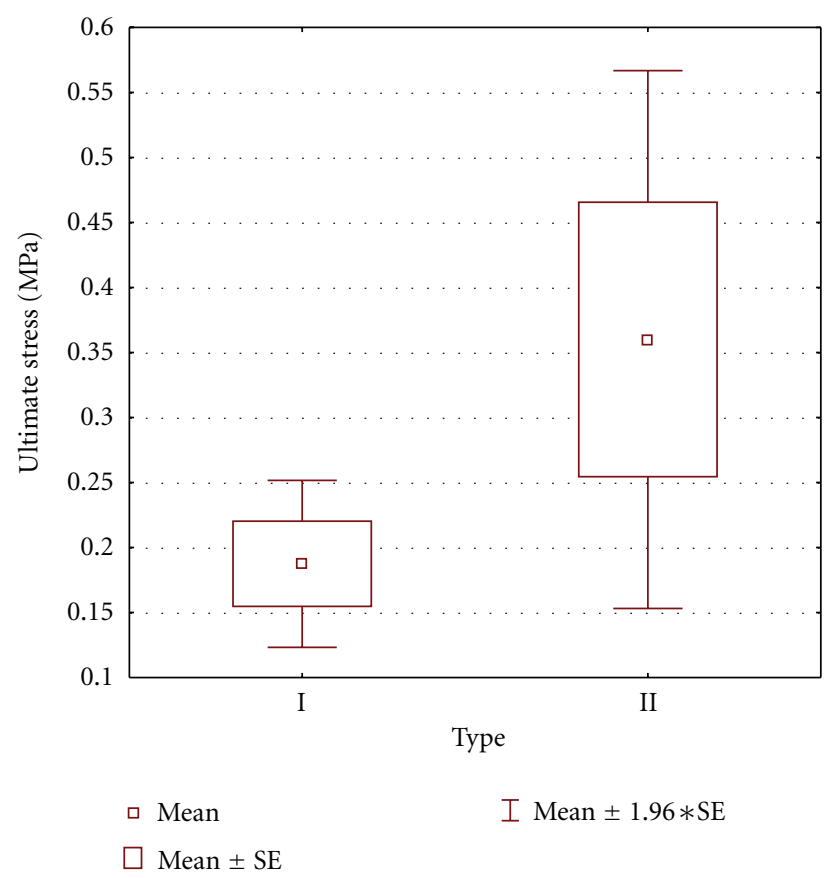

(c)

FIGURE 4: The moduli of elasticity, the ultimate strain, and ultimate stress of the group of pure PCL/PVA composite (type I) and the group of the PCL/PVA composite covered by HA layer (type II). There is a significant difference in the moduli of elasticity between these groups (determined by $t$-test; $P=0.04)$ (a) and also in the ultimate strain $(P<0.001)$ (b), but not in the ultimate stress $(P=0.26)(\mathrm{c})$. Mean is the mean value, $\mathrm{SE}$ is the standard error.

described in Section 2. The collected fractions were analyzed by fluorescence spectroscopy, and the cumulative release profile of FITC-dextran was calculated (Figure 5). The half-time of release from coaxial nanofibers was strongly dependent on the presence of a hydrophilic core polymer. Core/shell nanofibers containing FITC-dextran dissolved in 1\% PVA showed the highest burst release $(79 \%$ of FITC-dextran released in $24 \mathrm{~h}$ ). The half time of release was calculated as $\tau_{r}=18 \mathrm{~h}$. The release of FITC/dextran from fibers with $3 \%$ PVA showed a slower release; however, an intense burst 


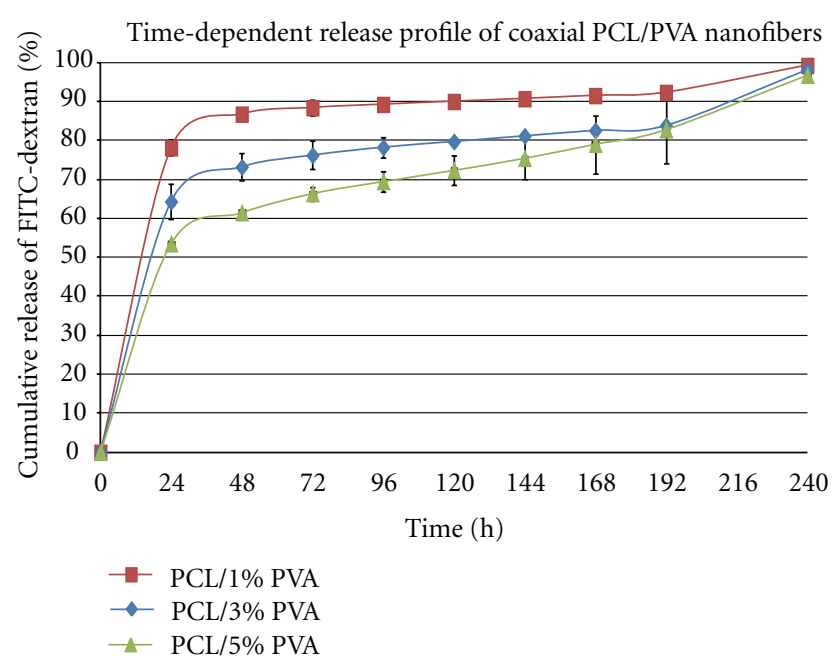

FIgURe 5: Time-dependent release profile of coaxial PCL/PVA nanofibers. Release of FITC-dextran from samples with different content of PVA core was analyzed using fluorescence spectroscopy. Samples were analyzed for $240 \mathrm{~h}$, and supernatants were collected in $24 \mathrm{~h}$ intervals (mean \pm standard deviation).

release was observed (65\% of FITC-dextran released in $24 \mathrm{~h}$ ). The half-time of release was prolonged to $24 \mathrm{~h}$. Interestingly, samples with 5\% PVA as the core polymer showed the most sustained release profile. The burst release was reduced to $52 \%$ of FITC-dextran release in $24 \mathrm{~h}$, and the half-time of release was shifted to $54 \mathrm{~h}$. The results clearly show that different concentrations of the water-soluble core significantly affect the release profiles of incorporated substances.

\section{Conclusion}

Pulsed laser deposition was proven to be a suitable method for HA coating of coaxial PCL/PVA nanofibers. The fibrous morphology of PCL/PVA nanofibers was preserved when the nanofiber scaffold was coated with thin layers of HA $(200 \mathrm{~nm}$ and $400 \mathrm{~nm})$. Increasing the thickness of HA, however, resulted in a gradual loss of this fibrous character. In addition, the biomechanical properties were improved after HA deposition on PCL/PVA nanofibers as the value of Young's moduli of elasticity significantly increased after HA deposition.

The proliferation and differentiation of MSCs on HAcoated scaffolds are separate processes. Our HA-coated nanofiber scaffolds clearly displayed a positive effect on the differentiation of MSCs into osteogenic cells but not on cell proliferation. The moderate effect of HA-coated nanofiber scaffolds on cell proliferation observed in our study could be improved, however, by exploiting core/shell nanofibers. Such a delivery system, based on coaxial spinning, can encapsulate proliferation stimulating factors that could be subsequently steadily released. This system seems to be a potentially promising one for the development of artificial bone tissue and bone healing. To conclude, thin-layer hydroxyapatite deposition on a nanofiber surface stimulated mesenchymal stem cell proliferation and their differentiation into osteoblasts.
The $800 \mathrm{~nm}$ HA layer was demonstrated to be optimal for bone tissue engineering application.

\section{Authors Contribution}

Both authors contributed equally.

\section{Acknowledgments}

This paper was supported by the Academy of Sciences of the Czech Republic (institutional research plans AV0Z50390703 and AV0Z50390512), Ministry of Education, Youth, and Sports of the Czech Republic (research program NPV II 2B06130), Grant Agency of the Academy of Sciences (Grant no. IAA500390702), the Grant Agency of the Charles University (Grant no. 96610, 97110, 330611, 384311, 164010), Grant Agency of the Czech Republic (Grant P304/10/1307, 109/09/P226), The Ministry of Education of the Czech Republic, project ERA-NET CARSILA no. ME 10145, the Internal Grant Agency Ministry of Health of the Czech Republic (no. NT12156-5/2011), and Grant by Czech Science Foundation (Grant no. GA202/09/1151).

\section{References}

[1] S. P. Bruder, N. Jaiswal, and S. E. Haynesworth, "Growth kinetics, self-renewal, and the osteogenic potential of purified human mesenchymal stem cells during extensive subcultivation and following cryopreservation," Journal of Cellular Biochemistry, vol. 64, no. 2, pp. 278-294, 1997.

[2] J. Ringe, C. Kaps, G. R. Burmester, and M. Sittinger, "Stem cells for regenerative medicine: advances in the engineering of tissues and organs," Naturwissenschaften, vol. 89, no. 8, pp. 338-351, 2002.

[3] A. I. Caplan, "Mesenchymal stem cells," Journal of Orthopaedic Research, vol. 9, no. 5, pp. 641-650, 1991.

[4] H. Peng and J. Huard, "Muscle-derived stem cells for musculoskeletal tissue regeneration and repair," Transplant Immunology, vol. 12, no. 3-4, pp. 311-319, 2004.

[5] Z. M. Huang, Y. Z. Zhang, S. Ramakrishna, and C. T. Lim, "Electrospinning and mechanical characterization of gelatin nanofibers," Polymer, vol. 45, no. 15, pp. 5361-5368, 2004.

[6] Y. Sakaguchi, I. Sekiya, K. Yagishita, and T. Muneta, "Comparison of human stem cells derived from various mesenchymal tissues: superiority of synovium as a cell source," Arthritis and Rheumatism, vol. 52, no. 8, pp. 2521-2529, 2005.

[7] J. Ringe, I. Leinhase, S. Stich et al., "Human mastoid periosteum-derived stem cells: promising candidates for skeletal tissue engineering," Journal of Tissue Engineering and Regenerative Medicine, vol. 2, no. 2-3, pp. 136-146, 2008.

[8] P. Kasten, J. Vogel, F. Geiger, P. Niemeyer, R. Luginbühl, and K. Szalay, "The effect of platelet-rich plasma on healing in critical-size long-bone defects," Biomaterials, vol. 29, no. 29, pp. 3983-3992, 2008.

[9] C. Weinand, I. Pomerantseva, C. M. Neville et al., "Hydrogel$\beta$-TCP scaffolds and stem cells for tissue engineering bone," Bone, vol. 38, no. 4, pp. 555-563, 2006.

[10] Y.-F. Chou, P. A. Zuk, T.-L. Chang, P. Benhaim, and B. M. Wu, "Adipose-derived stem cells and BMP2: Part 1. BMP2-treated adipose-derived stem cells do not improve repair of segmental femoral defects," Connective Tissue Research, vol. 52, no. 2, pp. 109-118, 2011. 
[11] P. A. Zuk, M. Zhu, P. Ashjian et al., "Human adipose tissue is a source of multipotent stem cells," Molecular Biology of the Cell, vol. 13, no. 12, pp. 4279-4295, 2002.

[12] N. Jaiswal, S. E. Haynesworth, A. I. Caplan, and S. P. Bruder, "Osteogenic differentiation of purified, culture-expanded human mesenchymal stem cells in vitro," Journal of Cellular Biochemistry, vol. 64, no. 2, pp. 295-312, 1997.

[13] M. W. Long, J. A. Robinson, E. A. Ashcraft, and K. G. Mann, "Regulation of human bone marrow-derived osteoprogenitor cells by osteogenic growth factors," Journal of Clinical Investigation, vol. 95, no. 2, pp. 881-887, 1995.

[14] M. W. Long, "Osteogenesis and bone-marrow-derived cells," Blood Cells, Molecules, and Diseases, vol. 27, no. 3, pp. 677-690, 2001.

[15] V. Karageorgiou and D. Kaplan, "Porosity of 3D biomaterial scaffolds and osteogenesis," Biomaterials, vol. 26, no. 27, pp. 5474-5491, 2005.

[16] Y. Kuboki, H. Takita, D. Kobayashi et al., "BMP-induced osteogenesis on the surface of hydroxyapatite with geometrically feasible and nonfeasible structures: topology of osteogenesis," Journal of Biomedical Materials Research, vol. 39, no. 2, pp. 190-199, 1998.

[17] C. P. A. T. Klein, P. Patka, H. B. M. Van der Lubbe, J. G. C. Wolke, and K. De Groot, "Plasma-sprayed coatings of tetracalciumphosphate, hydroxyl-apatite, and $\alpha$-TCP on titanium alloy: an interface study," Journal of Biomedical Materials Research, vol. 25, no. 1, pp. 53-65, 1991.

[18] P. Ducheyne, J. Beight, J. Cuckler, B. Evans, and S. Radin, "Effect of calcium phosphate coating characteristics on early post-operative bone tissue ingrowth," Biomaterials, vol. 11, no. 8, pp. 531-540, 1990.

[19] C. L. Tisdel, V. M. Goldberg, J. A. Parr, J. S. Bensusan, L. S. Staikoff, and S. Stevenson, "The influence of a hydroxyapatite and tricalcium-phosphate coating on bone growth into titanium fiber-metal implants," Journal of Bone and Joint Surgery - Series A, vol. 76, no. 2, pp. 159-171, 1994.

[20] Z. Zyman, J. Weng, X. Liu, X. Li, and X. Zhang, "Phase and structural changes in hydroxyapatite coatings under heat treatment," Biomaterials, vol. 15, no. 2, pp. 151-155, 1994.

[21] Y. C. Yang and E. Chang, "Influence of residual stress on bonding strength and fracture of plasma-sprayed hydroxyapatite coatings on Ti-6Al-4V substrate," Biomaterials, vol. 22, no. 13, pp. 1827-1836, 2001.

[22] M. Yoshinari, Y. Ohtsuka, and T. Derand, "Thin hydroxyapatite coating produced by the ion beam dynamic mixing method," Biomaterials, vol. 15, no. 7, pp. 529-535, 1994.

[23] J. M. Choi, H. E. Kim, and I. S. Lee, "Ion-beam-assisted deposition (IBAD) of hydroxyapatite coating layer on Ti-based metal substrate," Biomaterials, vol. 21, no. 5, pp. 469-473, 2000.

[24] Q. Bao, C. Chen, D. Wang, Q. Ji, and T. Lei, "Pulsed laser deposition and its current research status in preparing hydroxyapatite thin films," Applied Surface Science, vol. 252, no. 5, pp. 1538-1544, 2005.

[25] O. Blind, L. H. Klein, B. Dailey, and L. Jordan, "Characterization of hydroxyapatite films obtained by pulsed-laser deposition on Ti and Ti-6AL-4v substrates," Dental Materials, vol. 21, no. 11, pp. 1017-1024, 2005.

[26] D. Cui, "Advances and prospects on biomolecules functionalized carbon nanotubes," Journal of Nanoscience and Nanotechnology, vol. 7, no. 4-5, pp. 1298-1314, 2007.

[27] B. Pan, D. Cui, P. Xu et al., "Synthesis and characterization of polyamidoamine dendrimer-coated multi-walled carbon nanotubes and their application in gene delivery systems," Nanotechnology, vol. 20, no. 12, Article ID 125101, 2009.
[28] Z. Wang, J. Ruan, and D. Cui, "Advances and prospect of nanotechnology in stem cells," Nanoscale Research Letters, vol. 4, no. 7, pp. 593-605, 2009.

[29] T. J. Sill and H. A. von Recum, "Electrospinning: Applications in drug delivery and tissue engineering," Biomaterials, vol. 29, no. 13, pp. 1989-2006, 2008.

[30] S. Agarwal, J. H. Wendorff, and A. Greiner, "Use of electrospinning technique for biomedical applications," Polymer, vol. 49, no. 26, pp. 5603-5621, 2008.

[31] N. Bhardwaj and S. C. Kundu, "Electrospinning: a fascinating fiber fabrication technique," Biotechnology Advances, vol. 28, no. 3, pp. 325-347, 2010.

[32] C. Wenguo et al., "Electrospun nanofibrous materials for tissue engineering and drug delivery," Science and Technology of Advanced Materials, vol. 11, Article ID 014108, 2010.

[33] Y. Lu, H. Jiang, K. Tu, and L. Wang, "Mild immobilization of diverse macromolecular bioactive agents onto multifunctional fibrous membranes prepared by coaxial electrospinning," Acta Biomaterialia, vol. 5, no. 5, pp. 1562-1574, 2009.

[34] H. Jia, G. Zhu, B. Vugrinovich, W. Kataphinan, D. H. Reneker, and P. Wang, "Enzyme-carrying polymeric nanofibers prepared via electrospinning for use as unique biocatalysts," Biotechnology Progress, vol. 18, no. 5, pp. 1027-1032, 2002.

[35] J. Zhang, Y. Duan, D. Wei et al., "Co-electrospun fibrous scaffold-adsorbed DNA for substrate-mediated gene delivery," Journal of Biomedical Materials Research A, vol. 96, no. 1, pp. 212-220, 2011.

[36] N. Bölgen, I. Vargel, P. Korkusuz, Y. Z. Menceloğlu, and E. Pişkin, "In vivo performance of antibiotic embedded electrospun PCL membranes for prevention of abdominal adhesions," Journal of Biomedical Materials Research B, vol. 81, no. 2, pp. 530-543, 2007.

[37] K. Kim, M. Yu, X. Zong et al., "Control of degradation rate and hydrophilicity in electrospun non-woven poly(D,L-lactide) nanofiber scaffolds for biomedical applications," Biomaterials, vol. 24, no. 27, pp. 4977-4985, 2003.

[38] E. R. Kenawy, G. L. Bowlin, K. Mansfield et al., "Release of tetracycline hydrochloride from electrospun poly(ethyleneco-vinylacetate), poly(lactic acid), and a blend," Journal of Controlled Release, vol. 81, no. 1-2, pp. 57-64, 2002.

[39] G. Verreck, I. Chun, J. Rosenblatt et al., "Incorporation of drugs in an amorphous state into electrospun nanofibers composed of a water-insoluble, nonbiodegradable polymer," Journal of Controlled Release, vol. 92, no. 3, pp. 349-360, 2003.

[40] C. Y. Xu, R. Inai, M. Kotaki, and S. Ramakrishna, "Aligned biodegradable nanofibrous structure: a potential scaffold for blood vessel engineering," Biomaterials, vol. 25, no. 5, pp. 877886, 2004.

[41] X. Xu, X. Chen, X. Xu et al., "BCNU-loaded PEG-PLLA ultrafine fibers and their in vitro antitumor activity against Glioma C6 cells," Journal of Controlled Release, vol. 114, no. 3, pp. 307-316, 2006.

[42] J. Xie and C. H. Wang, "Electrospun micro- and nanofibers for sustained delivery of paclitaxel to treat C6 glioma in vitro," Pharmaceutical Research, vol. 23, no. 8, pp. 1817-1826, 2006.

[43] S. Y. Chew, J. Wen, E. K. F. Yim, and K. W. Leong, "Sustained release of proteins from electrospun biodegradable fibers," Biomacromolecules, vol. 6, no. 4, pp. 2017-2024, 2005.

[44] H. Nie, W. S. Beng, Y. C. Fu, and C. H. Wang, "Threedimensional fibrous PLGA/HAp composite scaffold for BMP2 delivery," Biotechnology and Bioengineering, vol. 99, no. 1, pp. 223-234, 2008.

[45] J. Zeng, A. Aigner, F. Czubayko, T. Kissel, J. H. Wendorff, and A. Greiner, "Poly(vinyl alcohol) nanofibers by electrospinning 
as a protein delivery system and the retardation of enzyme release by additional polymer coatings," Biomacromolecules, vol. 6, no. 3, pp. 1484-1488, 2005.

[46] A. Saraf, L. S. Baggett, R. M. Raphael, F. K. Kasper, and A. G. Mikos, "Regulated non-viral gene delivery from coaxial electrospun fiber mesh scaffolds," Journal of Controlled Release, vol. 143, no. 1, pp. 95-103, 2010.

[47] D. Liang, Y. K. Luu, K. Kim, B. S. Hsiao, M. Hadjiargyrou, and B. Chu, "In vitro non-viral gene delivery with nanofibrous scaffolds," Nucleic Acids Research, vol. 33, no. 19, pp. 1-10, 2005.

[48] H. Cao, X. Jiang, C. Chai, and S. Y. Chew, "RNA interference by nanofiber-based siRNA delivery system," Journal of Controlled Release, vol. 144, no. 2, pp. 203-212, 2010.

[49] H. Jiang, Y. Hu, P. Zhao, Y. Li, and K. Zhu, "Modulation of protein release from biodegradable core-shell structured fibers prepared by coaxial electrospinning," Journal of Biomedical Materials Research B, vol. 79, no. 1, pp. 50-57, 2006.

[50] S. Sahoo, L. T. Ang, J. C. H. Goh, and S. L. Toh, "Growth factor delivery through electrospun nanofibers in scaffolds for tissue engineering applications," Journal of Biomedical Materials Research A, vol. 93, no. 4, pp. 1539-1550, 2010.

[51] H. Li, C. Zhao, Z. Wang, H. Zhang, X. Yuan, and D. Kong, "Controlled release of PDGF-bb by coaxial electrospun dex$\operatorname{tran} /$ poly(L- lactide-co- $\varepsilon$-caprolactone) fibers with an ultrafine core/shell structure," Journal of Biomaterials Science, Polymer Edition, vol. 21, no. 6-7, pp. 803-819, 2010.

[52] W. Ji, F. Yang, J. J. J. P. Van Den Beucken et al., "Fibrous scaffolds loaded with protein prepared by blend or coaxial electrospinning," Acta Biomaterialia, vol. 6, no. 11, pp. 41994207, 2010.

[53] D. Lukáš, A. Sarkar, L. Martinová et al., "Physical principles of electrospinning (electrospinning as a nano-scale technology of the twenty-first century)," Textile Progress, vol. 41, no. 2, pp. 59-140, 2009.

[54] Y. Qian, X. Li, Y. Su, Q. Ke, and X. Mo, "Fabrication and characterization of polycaprolactone/ chlorophyllin sodium copper salt nanofibrous mats from 2,2,2-trifluoroethanol solution by electrospinning," Iranian Polymer Journal (English Edition), vol. 18, no. 3, pp. 265-274, 2009.

[55] J. Huard, A. Usas, A. M. Ho, G. M. Cooper, A. Olshanski, and $\mathrm{H}$. Peng, "Bone regeneration mediated by BMP4-expressing muscle-derived stem cells is affected by delivery system," Tissue Engineering A, vol. 15, no. 2, pp. 285-293, 2009.

[56] P. Kochova, "elfpy," 2011, http://code.google.com/p/elfpy/.

[57] D. Tvrdík, C. Povýšil, J. Svatošová, and P. Dundr, "Molecular diagnosis of synovial sarcoma: RT-PCR detection of SYTSSX1/2 fusion transcripts in paraffin-embedded tissue," Medical Science Monitor, vol. 11, no. 3, pp. MT1-MT7, 2005.

[58] J. Liao, X. Guo, D. Nelson, F. K. Kasper, and A. G. Mikos, "Modulation of osteogenic properties of biodegradable polymer/extracellular matrix scaffolds generated with a flow perfusion bioreactor," Acta Biomaterialia, vol. 6, no. 7, pp. 2386$2393,2010$.

[59] G. Ciapetti, L. Ambrosio, L. Savarino et al., "Osteoblast growth and function in porous poly $\varepsilon$-caprolactone matrices for bone repair: a preliminary study," Biomaterials, vol. 24, no. 21, pp. 3815-3824, 2003.

[60] J. S. Choi and H. S. Yoo, "Nano-inspired fibrous matrix with bi-phasic release of proteins," Journal of Nanoscience and $\mathrm{Na}$ notechnology, vol. 10, no. 5, pp. 3038-3045, 2010.

[61] R. Jakubova, A. Mickova, M. Buzgo et al., "Immobilization of thrombocytes on PCL nanofibres enhances chondrocyte proliferation in vitro," Cell Proliferation, vol. 44, no. 2, pp. 183 191, 2011.
[62] R. W. Forsey and J. B. Chaudhuri, "Validity of DNA analysis to determine cell numbers in tissue engineering scaffolds," Biotechnology Letters, vol. 31, no. 6, pp. 819-823, 2009.

[63] T. Mygind, M. Stiehler, A. Baatrup et al., "Mesenchymal stem cell ingrowth and differentiation on coralline hydroxyapatite scaffolds," Biomaterials, vol. 28, no. 6, pp. 1036-1047, 2007.

[64] L. A. Hails, J. C. Babister, S. Inglis, S. A. Davis, R. O. C. Oreffo, and S. Mann, "Inhibition of hydroxyapatite nanoparticle-induced osteogenic activity in skeletal cells by adsorption of serum proteins," Small, vol. 6, no. 18, pp. 1986-1991, 2010.

[65] C. Wang, Y. Duan, B. Markovic et al., "Proliferation and bonerelated gene expression of osteoblasts grown on hydroxyapatite ceramics sintered at different temperature," Biomaterials, vol. 25, no. 15, pp. 2949-2956, 2004.

[66] N. Ribeiro, S. R. Sousa, and F. J. Monteiro, "Influence of crystallite size of nanophased hydroxyapatite on fibronectin and osteonectin adsorption and on MC3T3-E1 osteoblast adhesion and morphology," Journal of Colloid and Interface Science, vol. 351, no. 2, pp. 398-406, 2010. 

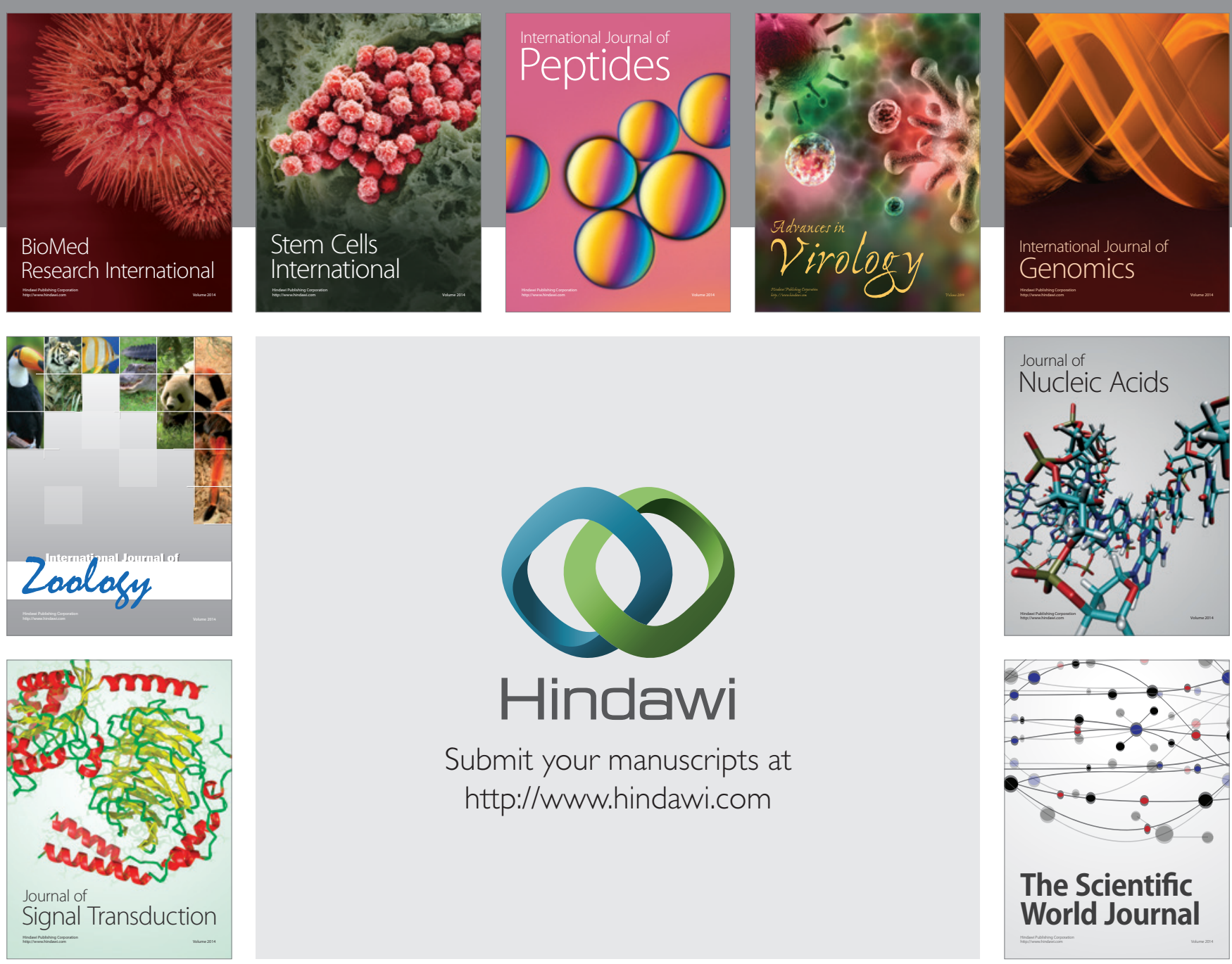

Submit your manuscripts at

http://www.hindawi.com
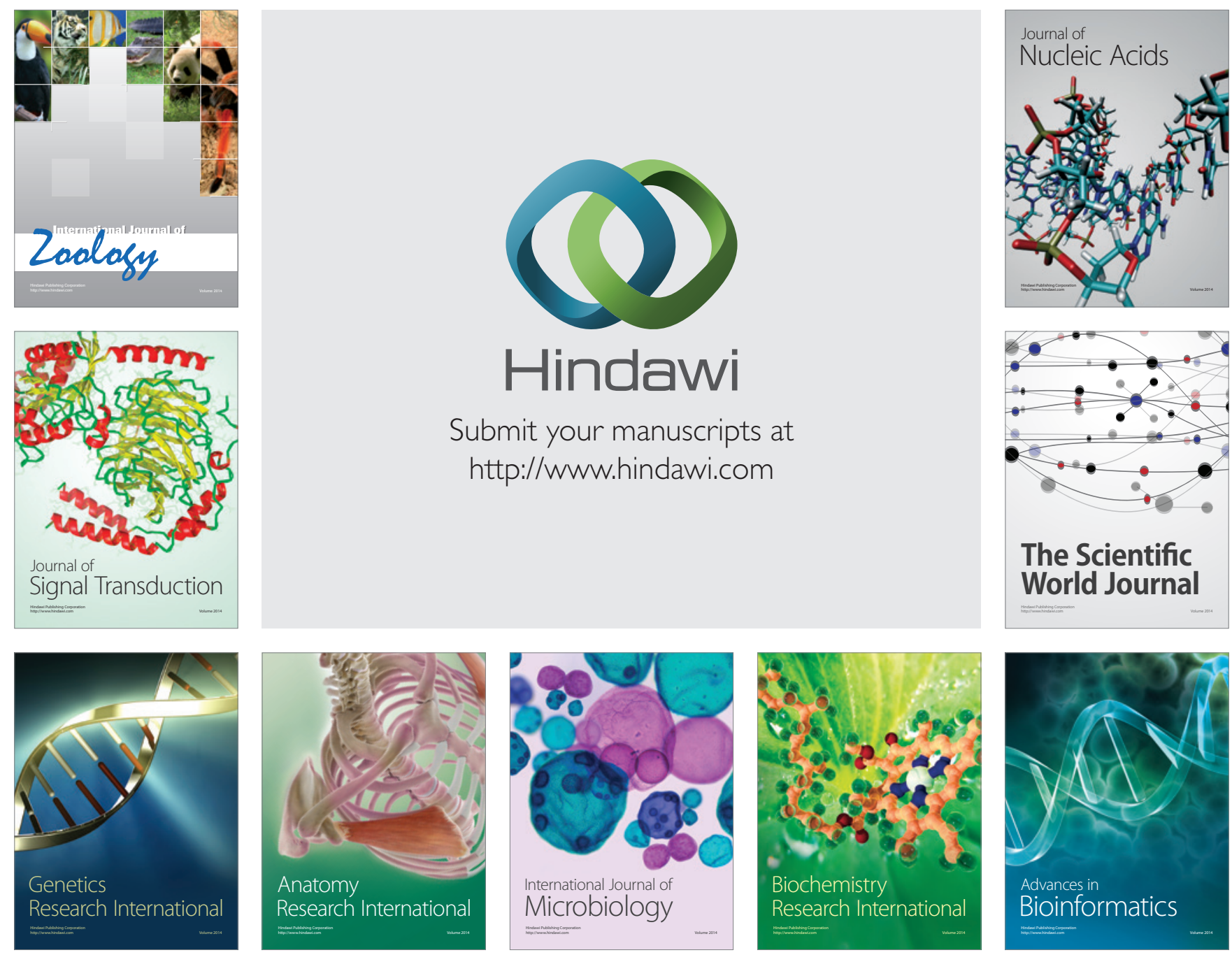

The Scientific World Journal
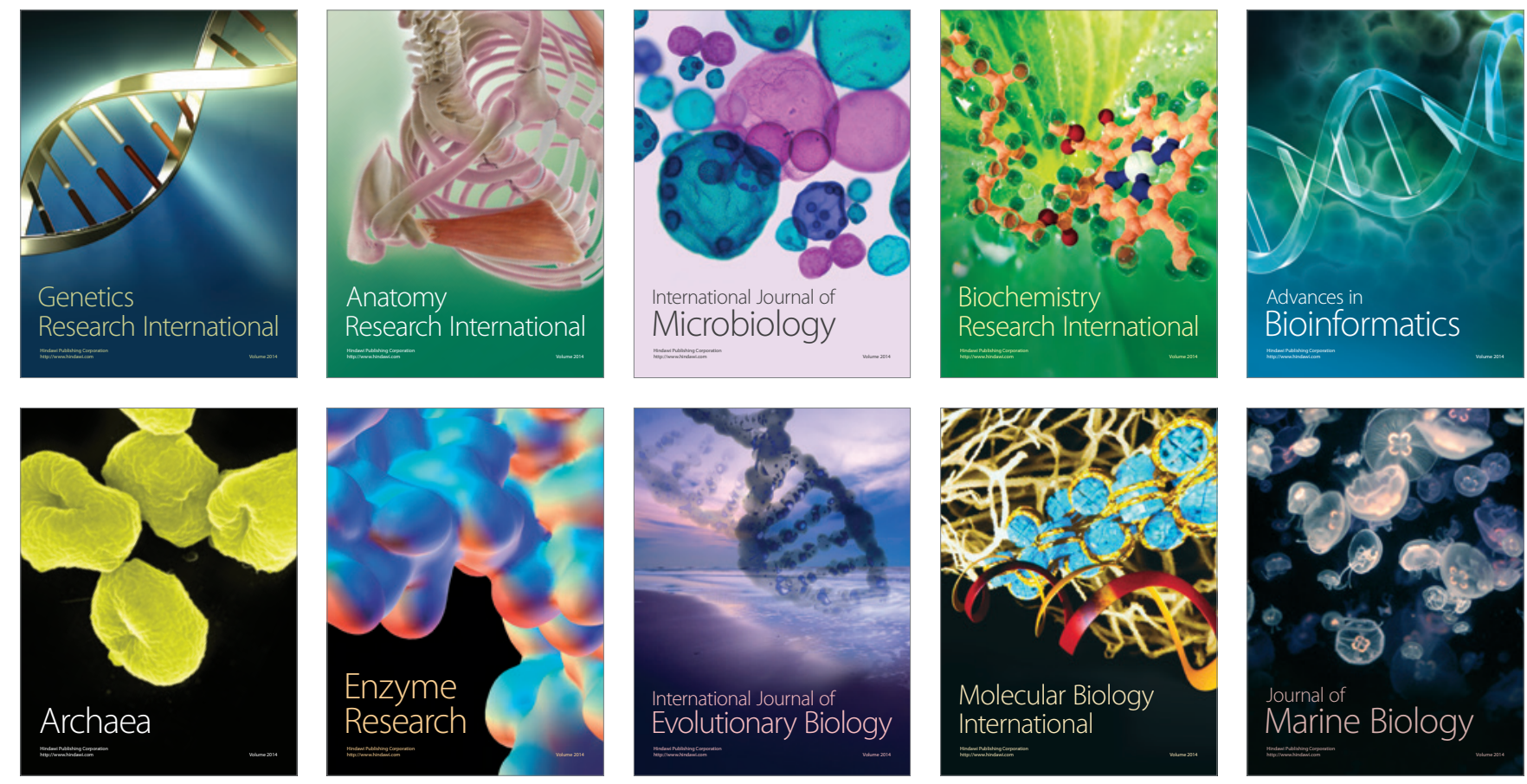